\title{
ПРОСТОРОВА НЕРІВНІСТЬ ТА ГАЛУЗЕВО-РЕГІОНАЛЬНА АСИМЕТРІЯ ІННОВАЦІЙНОГО РОЗВИТКУ ТРАНСПОРТНОЇ ІНФРАСТРУКТУРИ УКРАЇНИ
}

\author{
Дмитрієва Оксана Іллівна \\ кандидат економічних наук, доцент \\ Харківський національний автомобільно-дорожній університет (м. Харків, Україна) \\ ORCID: 0000-0001-9314-350X \\ oksanahnadu@gmail.com
}

\begin{abstract}
Статтю присвячено дослідженню економічної неоднорідності транспортного забезпечення та галузево-регіональної асиметрії просторового розміщення транспортної інфрраструктури в регіонах. Запропонований теоретико-методичний підхід ідентисрікаиії рівня просторової нерівності та галузево-регіональної асиметрії транспортної інфраструктури. Проведене матричне моделювання дозволило виявити, що всі об'єкти транспортної інфраструктури України можна класифрікувати на чотири квадранти. Подальша ідентифікація рівня галузевої та регіональної асиметрії та нерівності розвитку окремих територій дозволяє з'ясувати першочергові та пріоритетні напрями розвитку транспортної інфрраструктури.
\end{abstract}

Ключові слова: транспортна інфраструктура, інновації, просторова нерівність, галузево-регіональна асиметрія.

DOl: https://doi.org/10.32845/bsnau.2019.3.9

Постановка проблеми. Актуальність дослідження вказує на необхідність вирішення однієї 3 найважливіших проблем економіки - забезпечення інноваційного розвитку сучасної інфраструктури країни, що розширює доступність та підвищує безпеку функціонування транспортного комплексу.

Транспорт і забезпечення умов експлуатації транспортної інфрраструктури виступають у якості однієї із системних обставин функціонування економіки країни в цілому та окремих її територій зокрема, забезпечуючи їх територіальну цілісність, галузево-регіональну симетрію і єдину економічну систему саморозвитку. Галузево-регіональний розвиток транспортної інфрраструктури $€$ обов'язковою умовою реалізації інноваційних моделей, економічного зростання та покращення якості життя регіонів. Розвинена транспортна інфрраструктура забезпечує доступ споживачів до транспортних послуг, розширює можливості економіки регіонів у сфері транспортування вантажів, підтримує розвиток економіки країни в цілому. Але наявність регіональної нерівномірності, галузево-регіональної асиметрії інноваційного розвитку транспортної інфраструктури не тільки не обмежує ідентифікацію єдиного економічного простору території, а й підтримує розширення міжрегіонального взаємодії.

Тим часом слід враховувати, що недостатній рівень забезпеченості транспортної інфраструктури необхідними елементами веде до зниження ефективності їі розвитку, а незбалансований розвиток окремих видів транспорту в умовах обмеженості інвестиційних ресурсів призводить до їх нераціонального співвідношення в транспортному балансі окремої території. Від вирішення цієї проблеми залежить галузево-регіональний розвиток загальнонаціонального ринку транспортних послуг. У той же час аналіз сучасного стану транспортної інфраструктури свідчить про недостатній рівень ії розвитку і невисоку ефективність функціонування.

Аналіз останніх джерел, досліджень та публікацій. Аналіз монограффічної і періодичної літератури з даної проблематики показав, що в цілому наукових публікацій з питань розвитку транспортної інфраструктури достатньо для формування системно-цілісного уявлення про предмет дослідження. Істотний внесок у розробку економічних аспектів

функціонування і розвитку різних видів інфрраструктури внесли як зарубіжні, так і вітчизняні вчені, в числі яких можна визначити таких як Д. Ашауер, К. Вікселль, Дж. Кларк, А. Льюїс, У. Ростоу, П. Розенштейн-Родан, П. Самуельсон, А. Хіршмен, Я. Янгсон та ін. Окремі організаційно-економічні аспекти розвитку транспортної інфрраструктури на рівні регіону, в тому числі її просторової нерівності та ефрективності, досліджували такі вчені як Д. Дабиев [10], А. Давиденко [5], О. Єдін [2], О. Ємельянова [7], В. Ільчук [8], А. Кузнецова [9], Д. Клиновий [3], Д. Козакевич [4], Ю. Пащенко [5], Т. Пепа [3], Поповкин [6], В. Прейгер [7], Є. Сич [8], О. Собкевич [7], Л. Соколов [2], Л. Чернюк [3], Ю. Цвєтов [2]. При очевидній цінності наявних розробок з даної проблеми, на наш погляд, додаткових досліджень потребують питання методичного забезпечення оцінки рівномірності розвитку транспортної інфраструктури та її відповідності потребам регіону в здійсненні транспортно-економічних зв'язків. Цим обумовлені актуальність і наукова значимість вирішення поставленої проблеми, вибір теми, постановка мети і завдань дослідження.

Мета дослідження. Метою статті є окреслення та систематизація окремих аспектів просторової нерівності та галузево-регіональної асиметрії інноваційного розвитку транспортної інфрраструктури України.

Результати дослідження. Однією з основних цілей державної економічної політики $€$ боротьба $з$ негативними явищами, зумовленими економічної неоднорідністю ринкового простору і асиметрією просторового розміщення відтворювальних сил в регіонах. Важливість розвинутої транспортної інфрраструктурі для економіки країни є доведеним твердженням: інвестиції в транспортну інфраструктуру сприймаються як стимул попиту для здійснення економічного зростання і як певний внесок в частині економічного розвитку регіонів і сільських населених пунктів. Необхідно визначити напрями впливу транспортної інфраструктури на соціально-економічні показники регіону. Необхідно також враховувати, що, незважаючи на ступінь розвитку транспортної інфрраструктури (високої або низької), вона може здійснювати як позитивний, так і негативний вплив. Основні напрямки впливу транспортної інфрраструктури на розвиток регіону представлені в таблиці 1.

Таблиия 1 
Основні напрямки впливу транспортної інфраструктури на розвиток регіону

\begin{tabular}{|c|c|c|c|c|}
\hline \multirow{2}{*}{$\begin{array}{l}\text { Ступінь розвитку } \\
\text { інфрраструктури }\end{array}$} & \multicolumn{4}{|c|}{ Вид впливу } \\
\hline & \multicolumn{2}{|c|}{ Прямий } & \multicolumn{2}{|c|}{ Непрямий } \\
\hline & Позитивний & Негативний & Позитивний & Негативний \\
\hline висока & $\begin{array}{l}\text { 1. Забезпечення доступності } \\
\text { віддалених територій } \\
\text { 2. Скорочення транспортних } \\
\text { витрат } \\
\text { 3. Підвищення мобільності } \\
\text { населення }\end{array}$ & $\begin{array}{l}\text { 1. Збільшення кількості } \\
\text { торгових посередників } \\
\text { 2. Складна система } \\
\text { управління транспортом }\end{array}$ & $\begin{array}{l}\text { 1. Зростання кількості } \\
\text { туристських маршрутів } \\
\text { 2. Доступність соціальної } \\
\text { допомоги та послуг населенню }\end{array}$ & $\begin{array}{l}\text { 1. Збільшення міграційного } \\
\text { потоку } \\
\text { 2. Зростання екологічного } \\
\text { навантаження }\end{array}$ \\
\hline низька & $\begin{array}{l}\text { 1. Можливість розвитку } \\
\text { інфраструктури з урахуванням } \\
\text { останніх досягнень науки }\end{array}$ & \begin{tabular}{|l|} 
1. Значні інвестиції \\
2. Високі транспортні \\
витрати \\
3. Порушення транспортного \\
сполучення
\end{tabular} & $\begin{array}{l}\text { 1. Зниження екологічного } \\
\text { навантаження } \\
\text { 2. Збереження } \\
\text { сільськогосподарських земель } \\
\text { 3. Низький рівень ДТП }\end{array}$ & $\begin{array}{l}\text { 1. Низька транспортна } \\
\text { доступність послуг } \\
\text { 2. Заняття транспортом } \\
\text { земель, придатних для } \\
\text { сільського господарства }\end{array}$ \\
\hline
\end{tabular}

Запропоновано на основі [2, С. 24; 3, С.80; 4, C.132]

Однак не тільки транспортна інфраструктура впливає на стан регіону. Справедлива і зворотна залежність: наявні в регіоні проблеми негативним чином впливає на стан і розвиток транспортної інфраструктури [4, С.118; 5]. До них можна віднести: складні географічні умови, низькі економічні показники, неузгодженість дій регіональних і муніципальних властей при формуванні дорожньої мережі [4, С. 99; 5], високий ступінь зносу транспортних шляхів. Всі ці фрактори в цілому не дозволяють окремим регіонам в достатній мірі розвивати сучасну транспортну систему, відповідну останнім міжнародним стандартам [6, С.95; 7]. До виробничо-територіальної структури господарського комплексу країни входять спеціалізовані територіально-виробничі комплекси, які вирізняються спеціалізацією, масштабом, функціональним призначенням. Притаманний кожної території природно-ресурсний потенціал, виробнича діяльність вимагають відповідної транспортної інфраструктури. Для визначення просторової нерівності та галузевої асиметрії та його впливу на рівень інноваційного розвитку транспортної інфраструктури необхідно проаналізувати регіональний розріз концентрації певних видів виробничої діяльності, розподіл ВВП та ВРП за певними економічними районами країни (табл.2).

Таблиия 2

Територіально-виробнича структура економічних районів країни, у \% до загальної кількості

\begin{tabular}{|c|c|c|c|c|c|c|c|c|c|}
\hline Економічні райони і регіони & $\begin{array}{c}\text { Умовні } \\
\text { позначки }\end{array}$ & Територія & Населення & ВРП & $\begin{array}{c}\text { Продукція } \\
\text { промисловості }\end{array}$ & $\begin{array}{c}\text { Продукція } \\
\text { сільського } \\
\text { господарства }\end{array}$ & $\begin{array}{c}\text { Інвестиції в } \\
\text { основний } \\
\text { капітал }\end{array}$ & Експорт & Імпорт \\
\hline Україна & & 100 & 100 & 100 & 100 & 100 & 100 & 100 & 100 \\
\hline Донецький район & C_1 & 8,8 & 14,4 & 17,2 & 29,1 & 7,8 & 30 & 30 & 7,5 \\
\hline Донецька & R_4 & 4,4 & 9,4 & 12,1 & 20,2 & 4,9 & 21,1 & 21,1 & 5,6 \\
\hline Луганська & R 11 & 4,4 & 5,0 & 4,4 & 8,9 & 2,8 & 9,1 & 9,1 & 1,9 \\
\hline Карпатський район & C_2 & 9,3 & 13,0 & 8,0 & 5,1 & 10,1 & 4,1 & 4,1 & 6,1 \\
\hline Закарпатська & R_6 & 2,1 & 2,5 & 1,3 & 0,7 & 2,0 & 1,7 & 1,7 & 2,1 \\
\hline Івано-Франківська & R_8 & 2,3 & 2,9 & 1,8 & 1,4 & 2,2 & 1,0 & 1,0 & 0,8 \\
\hline Львівська & R_12 & 3,6 & 5,4 & 3,8 & 2,5 & 4,0 & 1,4 & 1,4 & 2,9 \\
\hline Чернівецька & R_23 & 1,3 & 1,9 & 0,8 & 0,3 & 1,8 & 0,1 & 0,1 & 0,1 \\
\hline Південний район & C_3 & 18,8 & 15,0 & 11,9 & 8,1 & 15,6 & 7,5 & 7,5 & 7,5 \\
\hline Миколаївська & $R \_13$ & 4,1 & 2,5 & 1,9 & 1,8 & 3,2 & 2,4 & 2,4 & 0,9 \\
\hline Одеська & R_14 & 5,4 & 5,1 & 4,5 & 3,6 & 4,4 & 3,4 & 3,5 & 5,5 \\
\hline Херсонська & R_20 & 4,7 & 2,3 & 1,6 & 0,7 & 3,7 & 0,5 & 0,5 & 0,3 \\
\hline Подільський район & C_4 & 10,1 & 8,8 & 4,4 & 3,2 & 12,8 & 1,5 & 1,5 & 1,4 \\
\hline Вінницька & R_1 & 4,3 & 3,5 & 2,0 & 1,3 & 6,0 & 0,6 & 0,6 & 0,4 \\
\hline Тернопільська & R_18 & 2,2 & 2,3 & 1,0 & 0,5 & 2,8 & 0,1 & 0,1 & 0,3 \\
\hline Хмельницька & R 21 & 3,4 & 2,8 & 1,3 & 1,3 & 3,8 & 0,5 & 0,5 & 0,5 \\
\hline Поліський район & C_5 & 16,9 & 9,9 & 6,0 & 4,7 & 12,2 & 2,7 & 2,7 & 2,9 \\
\hline Волинська & R_2 & 3,3 & 2,1 & 1,3 & 1,0 & 2,7 & 0,6 & 0,6 & 1,4 \\
\hline Житомирська & R_5 & 5 & 2,7 & 1,4 & 1,0 & 3,0 & 0,7 & 0,7 & 0,4 \\
\hline Рівненська & R 16 & 3,3 & 2,4 & 1,5 & 1,1 & 2,7 & 0,6 & 0,6 & 0,5 \\
\hline Чернігівська & R 24 & 5,3 & 2,3 & 1,5 & 1,2 & 3,5 & 0,5 & 0,5 & 0,3 \\
\hline Придніпровський район & C_6 & 13,9 & 13,4 & 15,8 & 26,5 & 14,2 & 28,2 & 28,2 & 14,5 \\
\hline Дніпропетровська & R_3 & 5,3 & 7,2 & 9,8 & 17,3 & 6,3 & 19,6 & 19,6 & 10,0 \\
\hline Запорізька & R7 7 & 4,5 & 3,8 & 4,5 & 8,2 & 3,8 & 7,9 & 7,9 & 4,1 \\
\hline Кіровоградська & R 10 & 4,1 & 2,1 & 1,3 & 0,8 & 3,9 & 0,5 & 0,5 & 0,2 \\
\hline Східний район & C_7 & 13,9 & 11,8 & 11,6 & 11,7 & 13,9 & 7,4 & 7,4 & 4,9 \\
\hline Полтавська & $R \_15$ & 4,8 & 3,2 & 3,8 & 5,1 & 5,4 & 3,7 & 3,7 & 1,4 \\
\hline Сумська & $\mathrm{R} \_17$ & 3,9 & 2,5 & 1,6 & 1,5 & 3,0 & 1,3 & 1,3 & 0,5 \\
\hline Харківська & R 19 & 5,2 & 5,9 & 6,0 & 4,9 & 5,3 & 2,2 & 2,2 & 2,8 \\
\hline Центральний район & C_8 & 8,3 & 12,5 & 24,3 & 9,9 & 12,4 & 15,5 & 15,5 & 47,3 \\
\hline Київська (вкл. м. Київ). & R 9 & 4,8 & 9,6 & 22,4 & 7,4 & 6,4 & 14,2 & 14,6 & 46,1 \\
\hline Черкаська & $\mathrm{R} 22$ & 3,5 & 2,7 & 1,8 & 2,4 & 5,9 & 1,2 & 1,2 & 1,1 \\
\hline
\end{tabular}

Складено на основі [11; 12] 
Дані табл.1 свідчать, що оптимальна структура економіки країни має базуватися на балансу інтересів територій $з$ приводу забезпечення їх сталого розвитку за умов максимального використання наявного природно-ресурсного потенціалу [8, С.93]. При цьому, оптимальна галузево-регіональна структура має забезпечувати економічно ефективне та оптимальне виробництво при раціональній спеціалізації у загальнодержавному поділу праці [9; 10].

Таке структурне планування галузевої та територіальної спеціалізації в значній мірі визначається розвитком транспортної інфраструктури [9; 10]. Саме розвиток транспортної інфраструктури створює умови, з одного боку, для концентрації, кооперування і комбінування різного роду виробництв, поглиблення регіонально-галузевого поділу праці, планомір-

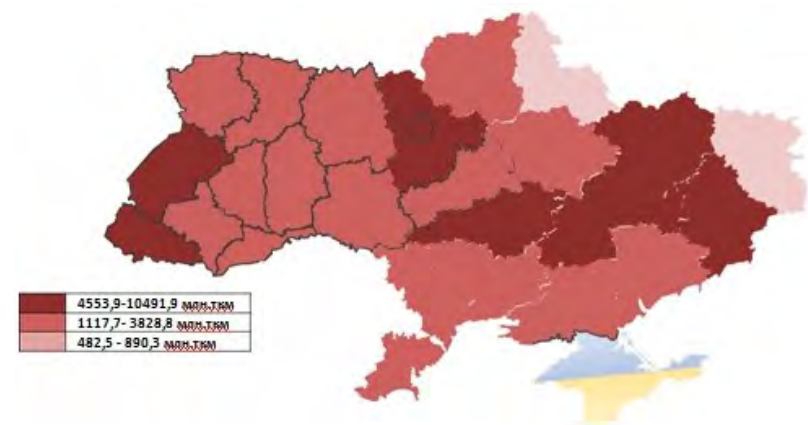

Вантажооборот автомобільного транспорту за регіонами

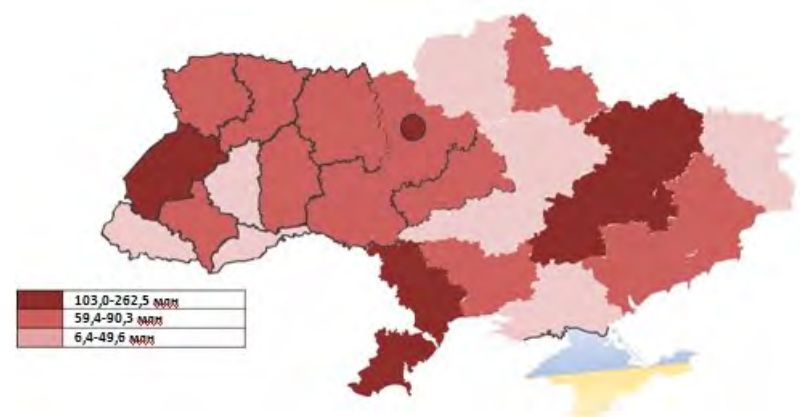

Перевезення пасажирів автомобільним транспортом Джерело [11, 12] (автобусами) за регіонами

\section{Рис.1. Обсяги надання транспортних послуг у 2018 р. за регіонами}

Для дослідження просторової нерівності та галузеворегіональної асиметрії було визначено наступні показники [2, C.45-50; 3]:

1. Коефріцієнт співвідношення вантажних і пасажирських перевезень:

$$
K_{\text {Bnn }}=\frac{t_{B_{n}}}{t_{n}},
$$

де $t_{8}-$ перевезення вантажів, млн. т; $t_{n}$ - перевезення пасажирів, млн. осіб.

2. Для повної характеристики транспортної інфрраструктури регіону необхідно додатково розрахувати показник щільності вантажний маси $\left(K_{n л}\right)$ в регіоні:

$$
K_{n л}=\frac{t_{\text {вinp }}+t_{\text {приб }}}{S}
$$
буття вантажів; $S$ - площа території регіону. ртною мережею [54, С.282]:

$$
K_{e i}=\frac{L_{i}}{\sqrt{S_{i} \times H_{i}}},
$$
торії, млрд. грн. ного розвитку всього суспільного виробництва, з другого - розгалуження міжрайонних, внутрішньорайонних транспортноекономічних зв'язків, територіального розміщення виробництва і споживання продукції, сталого розвитку всього регіону [2; 3; 4; 5]. До виробничо-територіальної структури господарського комплексу країни входять спеціалізовані територіально-виробничі комплекси, які вирізняються спеціалізацією, масштабом, функціональним призначенням. На просторову нерівність та галузеву асиметрію окрім рівня розвитку економіки регіону взагалі має великий вплив рівень розвитку територіальної транспортної інфраструктури (рис.1). Дані рис.1 свідчать, що у 2018 році за регіонами спостерігається нерівномірний розподіл перевезень вантажів та пасажирів всіма видами транспорту.

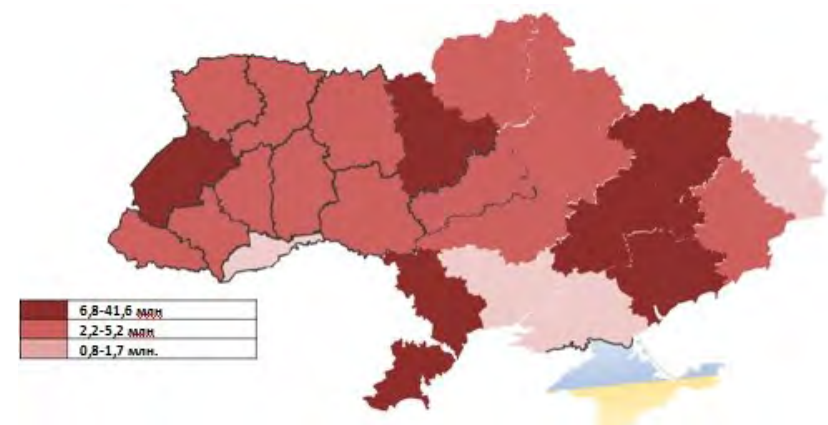

Відправлення пасажирів залізничним транспортом загального користування за регіонами

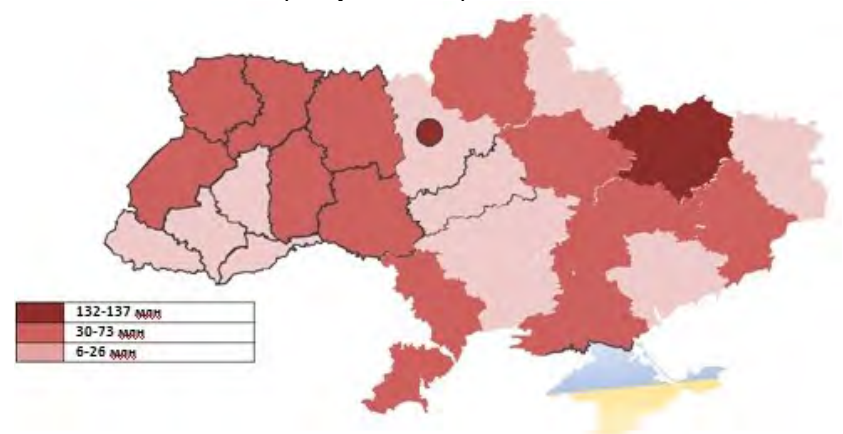

Перевезення пасажирів тролейбусним транспортом за регіонами

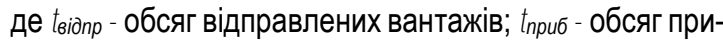

3. Коефіцієнт Енгеля забезпеченості регіону транспо-

де $L_{i}$ - протяжність доріг на даній i-й території, км; $S_{i}-$ площа $і$-й території, тис. кв. км, $H_{i}-$ чисельність населення, що обслуговується даними видами інфраструктури, тис. осіб, $Q_{i}$ - валова продукція виробничих підприємств на даній тери-

4. Якщо в формулу коефіцієнта Енгеля під знак радикала замість чисельності населення підставити число насе- 
лених пунктів, отримаємо наступний показник, що є модифікацією попереднього і також дозволяє оцінити рівень забезпеченості автодорожньої мережею - коефіцієнт Гольця. Він має більш глибокий зміст, так як транспортна мережа з'єднує між собою саме населені пункти [4, С.283]:

$$
K_{c i}=\frac{L_{i}}{\sqrt[3]{S_{i} \times N_{i}}},
$$

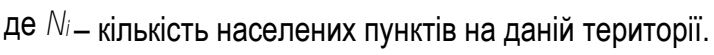
5. Для розрахунку коефіцієнтів Успенського $\left(K_{y}\right)$ і Василевського $\left(K_{6}\right)$ використовуються наступні формули [4, C.283]:

$$
\begin{gathered}
K_{y i}=\frac{L_{i}}{\sqrt[3]{S_{i} \times H_{i} \times t_{\text {вìn }}}}, \\
K_{i i}=\frac{L_{i}}{\sqrt[3]{S_{i} \times H_{i} \times Q_{i}}},
\end{gathered}
$$

6. Оцінити забезпеченість досліджуваної території автодорожньою мережею дозволяє показник - щільність дорожньої мережі, яку можна розраховувати у двох варіантах: на $1000 \mathrm{~km}^{2}\left(d_{s}\right)$ і на 10 тисяч осіб $\left(d_{H}\right)$. У першому випадку можна оцінити транспортну забезпеченість з урахуванням площі досліджуваної території, у другому - з урахуванням чисельності населення:

$$
\begin{aligned}
d_{s i} & =\frac{1000 \times L_{i}}{S_{i}}, \\
d_{H i} & =\frac{1000 \times L_{i}}{H_{i}},
\end{aligned}
$$

7. Інтегральна транспортна доступність (G):

$$
G=q \cdot\left[1-\left(t_{1}+t_{2}\right)\right]+Z,
$$

де $q$ - часткова зв'язність (лінійне сусідство), км; $t_{1}-$ коефіцієнт проміністості; $t_{2}$ - коефіцієнт резерву конфігурації; Z - транспортний фокус території, км.

8. Мінімальна (максимальна) відстань $G_{\min }\left(G_{\max }\right)$ від однієї прикордонної точки суб'єкта до іншого протилежного:

$$
T_{\min (\max )}=G_{\min }\left(G_{\max }\right) \text {, }
$$

9. Мінімальний (максимальний) час $t_{\min }\left(t_{\max }\right)$ для подолання відстані $G_{\min }\left(G_{\max }\right)$ з використанням найбільш швидкісного виду транспорту:

$$
t_{\min (\max )}=G_{\min (\max )} / V_{c p},
$$

де $V_{c p}$ - середня швидкість руху даного виду транспорту (км / год.).

10. Середній час (tсp) транспортної доступності:

$$
T_{c p}=\left(t_{\min }+t_{\max }\right) / 2
$$

11. Час $(T)$, необхідний на подолання всієї наземної транспортної мережі даного суб'єкта (автомобільних (Saвm), залізничних $\left(S_{3}\right)$ і річкових (морських) (Sріч./мор.) транспортних шляхів):

$T=S_{\text {aвm }} / \mathrm{V}_{\text {ср.авт }}+S_{3} / V_{\text {cp.3 }}+S_{\text {piч./mop. }} / \mathrm{V}_{\text {cp. pi4./mop. }}$

12. Коефіцієнт доступності $(K)$ :

$$
K=T / t_{c p},
$$

13. Щільність (густота) шляхів сполучення характеризує забезпеченість регіону транспортними шляхами і показує, скільки кілометрів транспортних шляхів доводиться на 1000 км² площі території:

$$
\Gamma=\frac{L_{e}}{S_{i}},
$$

де $L_{e}$ - експлуатаційна довжина транспортного шляху; $S_{i}$ - площа території регіону.

14. Щільність (густота) мережі, що характеризує транспортну забезпеченість населення території і показує, скільки кілометрів транспортних шляхів припадає на 10000 жителів, визначається за формулою:

$$
\Gamma_{M}=\frac{L_{e}}{S_{i}},
$$

де $\mathrm{H}_{i}$ - чисельність населення регіону.

15. Транспортна рухливість (мобільність) населення

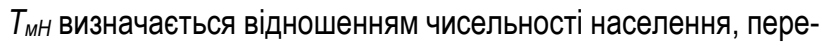
везеного автотранспортом громадського користування $\left(\Sigma H_{\text {nac }}\right)$ до загальної чисельності населення території $\left(H_{i}\right)$

$$
T_{\mu H}=\frac{\sum H_{n a c}}{H_{i}},
$$

До першої групи показників, які характеризують просторову нерівність, відносяться: коефіцієнт Енгеля (3); коефіцієнт Гольця (4); щільність дорожньої мережі на 1000 кв. км (7); інтегральна транспортна доступність (9); мінімальна (максимальна) відстань від однієї прикордонної точки суб'єкта до іншого протилежного (10); мінімальний (максимальний) час для подолання мінімальної (максимальної) відстані з використанням найбільш швидкісного виду транспорту (11); середній час транспортної доступності (12); щільність (густота) шляхів сполучення (15). Показники, які за ознаками впливу на рівень соціально-економічного розвитку території доцільно віднести до групи галузево-регіональної асиметрії, наступні: коефіцієнт співвідношення вантажних і пасажирських перевезень (1); показник щільності вантажний маси в регіоні (2); коесріцієнти Успенського (5) і Василевського (6); щільність дорожньої мережі на 10 тисяч осіб (8); час, необхідний на подолання всієї наземної транспортної мережі (13); коефіцієнт доступності (14); щільність (густота) мережі, що характеризує транспортну забезпеченість населення території (16); транспортна рухливість (мобільність) населення (17). 
Для комплексної оцінки просторової нерівності та галузево-регіональної асиметрії пропонується скористатися методом таксономії. Розрахунок інтегральних характеристик виконано на основі вектора розмірності $D_{(n)}$. Вектор відмінностей $D_{(n)}$ показує ступінь віддаленості (близькості) всіх реальних територіальних одиниць від умовної або галузево-регіональної симетрії, що має найкращі або найгірші оціночні умови, в нашому випадку показує ступінь віддаленості від умовного «найгіршого» району.

Для проведення типології транспортної просторової нерівності та галузево-регіональної симетрії використовуємо алгоритм оціночної класифікації ArcView GIS [55], де в якості інтегрального показника виступає показник транспортного навантаження на територію.

Показники нормуємо, для чого, використовуємо формулу:

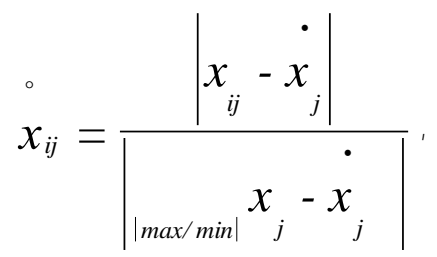

де $i=1,2,3, n ; j=1,2$, ,m; $n$ - кількість територіальних одиниць; $m$ - кількість показників $\left(x_{i j}\right) ; x$ - найкращі (або найгірші) для кожного показника оцінні значення; $\max / \min X$ - екстремальні значення показників, найбільш відрізняються від величин $x$

$\left|\underset{\min }{x_{j}-\dot{x}} j_{j}^{\max /}\right|>\mid \max _{j}-\dot{x} x_{j}$ $\min$

$x$, якщо

$\left|\underset{\min }{x_{j}-x_{j}}\right| \leq\left|\begin{array}{c}\max / \\ x_{j}-x_{j}\end{array}\right|$ $\max$

$x, \quad$ якщо
Дане нормування дає можливість виявити відхилення всієї системи показників від «найкращих» або «найгірших» оціночних значень і тим самим правильніше порівняти їх між собою. Знаходимо сумарні значення показників:

$$
S_{i}=\frac{\left|x_{i j}-x_{j}\right|}{\left.\sum_{j=1}^{m}\right|_{\max / \min } x_{j}-x_{j} \mid},
$$

Такі величини приблизно характеризують оцінку транспортної просторової нерівності територіальних одиниць та галузево-регіональної асиметрії за рахунок того, що чим сильніше їх показники відрізняються від найкращих значень, тим величина $S_{i}$ буде більше, тим гірше оціночна характеристика транспортної просторової нерівності відповідної територіальної одиниці (і навпаки для найгірших значень). Середні для таксонів величини Si дозволяють дати їм якісні характеристики-оцінки (наприклад, «дуже погані», «погані», «хороші» тощо), а також кількісно зіставляти їх між собою.

Ранжування територіальних одиниць, досягається обчисленням вектора розмірності $D^{\circ}{ }_{(n)}$. Вектор відмінностей $D^{\circ}{ }_{(n)}$ показує ступінь віддаленості (близькості) всіх реальних територіальних одиниць та галузево-регіональної асиметрії від умовної, яка має найкращі або найгірші оціночні умови (в нашому випадку віддаленості від умовного «найгіршого» району):

$$
d_{i k}=\sqrt{\sum_{j=1}^{m}\left(x_{i j}-x_{k j}\right)^{2}}
$$

Візуалізація ступеню просторової нерівності та галузевої асиметрії транспортної інфраструктури наведено на рис.2. 


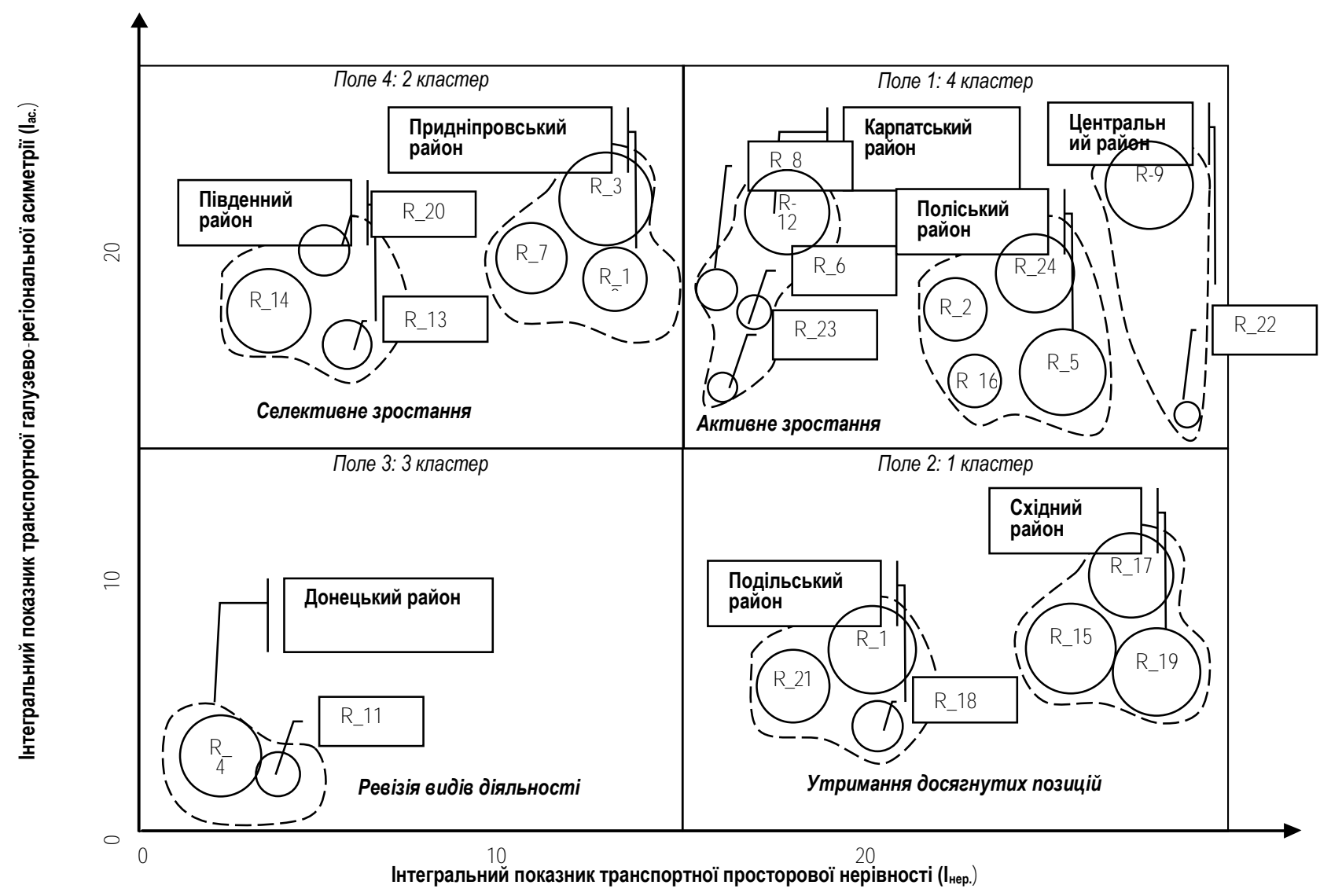

Ум. позначки див. табл. 1

Джерело: побудовано автором.

Рис. 2. Ступінь просторової нерівності та галузево-регіональної асиметрії транспортної інфраструктури регіонів України

Перше поле - це четвертий кластер (регіони Карпатського району: Закарпатська, Івано-Франківська, Львівська та Чернівецька області; Поліського району: Волинська, Житомирська, Рівненська та Чернігівська області; Центрального району: Київської (у т.ч. м. Київ) та Черкаської областей). Четвертий кластер собою таксон з великою величиною транспортної галузево-регіональної асиметрії та транспортної просторової нерівності. До цього таксону потрапили регіони з містами-мільйонниками, де просторова нерівність та галузеворегіональна асиметрія максимальна. Такий стан пояснюється інтенсивною урбанізацією та автомобілізацією даної групи. Для даного таксона рекомендується стратегія активного зростання. Вона полягає у підвищенні рівня забезпечення транспортної доступності, якості послуг громадського транспорту для населення. Це можливо здійснити завдяки оптимізації роботи міського та приміського пасажирського транспорту; постійного оновлення пасажирського рухомого складу транспортними засобами, що відповідають техніко-економічним вимогам і не поступаються світовим аналогам; розширення системи тарифного регулювання на видах громадського транспорту; підвищення якості приміських пасажирських залізничних перевезень, з комплексним розвитком високошвидкісних ділянок залізниць і швидкісних систем, що сприяють забезпеченню зручних, комфортних для жителів, умов поїздки, зниження витраченого часу учасника транспортних перевезень на пересування; продовження роботи з адаптації пішохідних шляхів, світлофорів, паркувальних місць, зупинок громадського транспорту до потреб інвалідів; організації перевезень пасажирів за соціально значимими маршрутами і цінової доступності транспортних послуг.

Друге поле - це перший кластер: регіони Подільського району (Вінницької, Тернопільської та Хмельницької областей); Східного району (Полтавської, Сумської та Харківської областей). Цей таксон має велику величину транспортної просторової нерівності та відносно невелику галузево-регіональну асиметрію. До цього таксону також потрапили регіони з містами-мільйонниками. Велика просторова нерівність вимагає впровадження стратегії утримання досягнутих позицій, що пов'язано з практичною відсутністю комплексного розвитку регіонального транспорту. Підвищення рівня галузево-регіональної симетрії вимагає стійкого розвитку промислового сектора і забезпечення логістики їх товарів. В даний час держава стикається з проблемою конкуренції всередині єдиної транспортної системи різних видів транспорту, а цього не повинно бути. Тому одним із першочергових завдань держави $€$ побудова транспортної системи таким чином, щоб загальнодоступні види транспорту не конкурували між собою, а взаємно доповнювали один одного. Окрім того, для регіонів цього таксону характерна недостатня впорядкованість роботи автомобільного транспорту загального користування. Наявність на автобусних маршрутах нелегальних перевізників, які здійснюють перевезення населення з порушеннями швидкісного режиму і правил дорожнього руху. Це призводить до перевантаженості міських доріг, виникнення пробок, особливо в години «пік», в результаті збільшуються витрати часу на пересування до необхідного об'єкту. 
Третє поле - це третій кластер: регіони Донецького району (Донецька та Луганська області). Цей таксон має самий низький та асиметричний рівень розвитку транспортної інфраструктури. Експерти відзначають, що основною проблемою розвитку транспортної інфраструктури в даній підгрупі крім зростання допустимих навантажень $є$ інтенсивний знос через відсутність ремонту і скорочення витрат на будівництво нових доріг. Наявність в регіоні значних за площею територій, неохоплених сучасною транспортною інфрраструктурою; низька якість дорожнього покриття автомобільних доріг; відсутність регулярних перевезень місцевого значення (головним чином у зв'язку з військовим конфліктом на сході України). У більшості районів регіону населення через поганий стан автомобільних доріг або їх відсутність, або отримує соціальні послуги в недостатньому обсязі, або не отримує їх зовсім. Зношеність парку транспортних засобів загального користування. Відсутність необхідного для задоволення потреб осіб з обмеженими можливостями, кількості спеціально обладнаних транспортних засобів. Через відсутність регулярного транспортного сполучення між населеними пунктами багато жителів сільських районів краю не мають змоги працевлаштуватися на робочі місця з гідною оплатою праці.

Четверте поле - це другий кластер: регіони Південного району (Миколаївської, Одеської та Херсонської областей); Придніпровського району (Дніпропетровської, Запорізької та Кіровоградської областей). Цей таксон має високий рівень транспортної галузево-регіональної асиметрії та невелику величину просторової нерівності транспортної інфраструктури. Така ситуація вимагає впровадження стратегії селективного зростання, що втілюється у розвиток лише тих су- б'єктів транспортної інфраструктури, які на даний момент мають більший високий транспортний потенціал достатній для транспортування поточного обсягу вироблених товарів, забезпечення транспортної мобільності населення. Населення, яке проживає у великих містах цього таксону, щодня витрачає багато часу, добираючись на роботу і назад, через автомобільні пробки, що виникають внаслідок низької пропускної здатності міських автодоріг і їх поганий стан, особливо в зимовий Проведене дослідження показало, що розвиток транспортної інфраструктури України проявляється нерівномірно. Особливо вплив посилено у східній частині республіки, так як тут найбільша густота автомобільних доріг, інтенсивність руху. Залежить це і від ряду факторів, таких як якість дорожньої мережі, її технічна оснащеність, завантаженість комунікацій, структура транспортного потоку, швидкість транспортних засобів, освоєність і озеленення придорожньої смуги. Запропоноване моделювання ступеню просторової нерівності та галузево-регіональної асиметрії транспортної інфраструктури регіонів України може бути використано при вирішенні проблем розвитку транспортної інфраструктури і при територіальному плануванні. Об'єкти транспортної інсрраструктури та організації, які надають транспортні послуги, є невід'ємною частиною соціально-економічної інфраструктури регіону комплексу організацій і об'єктів, що забезпечують сприятливі умови діяльності всіх суб'єктів економіки, а також комфортне проживання людей на його території. Тому для забезпечення всебічного розвитку регіонів, забезпечення скорочення диференціації українських регіонів за рівнем і якістю життя населення дуже важливо проводити комплексні роботи по створенню і подальшому розвитку інфраструктурних об'єктів, що відповідають вимогам сьогодення.

\section{Список використаної літератури:}

1. Національна транспортна стратегія України на період до 2030 року. Електронний ресурс. Режим доступу: https://zakon.rada.gov.ua/laws/show/430-2018-\%D1\%80

2. Єдін О. Транспортна політика в Україні / О. Єдін, Ю. Цвєтов, Л. Соколов // Економіка України. - 2000. - № 1. - С. 24-34.

3. Клиновий Д. В. Розміщення продуктивних сил та регіональна економіка України / Д. В. Клиновий, Т. В. Пепа; за ред. Л. Г. Чернюк. - К. : Центр навчальної літератури, 2006. - 728 с.

4. Козакевич Д. М. Производственно-транспортные модели в перспективном отраслевом планировании / Д. М. Козакевич. - М.: Экономика, 2013. - 295 с.

5. Пащенко Ю. Є. Перспективи розвитку транспортного комплексу / Ю. Є. Пащенко, А. М. Давиденко, Л. Г. Чернюк - К. : Либідь,2008. - 269 с.

6. Поповкин В. А. Регионально-целостный подход в экономике / В. А. Поповкин - К.: Наукова думка, 2003. - 218 с.

7. Прейгер Д. Щодо реалізації та розвитку транзитного потенціалу України: аналітична записка [Електронний ресурс] / Д. Прейгер, О. Собкевич, О. Ємельянова. - 2012. - Режим доступу: http://www.niss.gov.ua/articles/818. - Назва з екрану.

8. Сич Є. М. Інноваційно-інвестиційні комплекси транспортної галузі: методологія формування та розвитку: Монографія /

Є. М. Сич, В. П. Ільчук. - К.: Логос, 2006. - 264 с.

9. Кузнецова А. И. Инфраструктура как необходимое условие устойчивого развития инновационной экономики города // Вестник Московского университета им. С. Ю. Витте. Серия 1: Экономика и управление. 2012. № 1 (1). С. 45-50.

10. Дабиев Д. Ф., Дабиева У. М. Оценка транспортной инфраструктуры макрорегионов // Международный журнал прикладных и фундаментальных исследований, 2015. №11. С. 283-284. URL: http://applied-research.ru/pdf/2015/11-2/7726.pdf.

11. Статистичний збірник "Транспорт і зв'язок України - 2018". Державна служба статистики України. / За редакцією I. Петренко. Вид-во: ТОВ «Бук-Друк», 2019. - 152 с.

12. Державна служба статистики України. URL: http://www.ukrstat.gov.ua/ 
Dmytriieva O. I., PhD in Economics, Associate Professor, Kharkiv national automobile and highway university (Kharkiv, Ukraine)

Spatial inequality and industry-regional asymmetry of innovative development of transport infrastructure in Ukraine

The article is devoted to the study of economic heterogeneity of transport support and sector-regional asymmetry of spatial location of transport infrastructure in regions. The theoretical and methodological approach of identification of the level of spatial inequality and branch-regional asymmetry of transport infrastructure is proposed. The conducted matrix modeling revealed that all the objects of transport infrastructure of Ukraine can be classified into four quadrants. Further identification of the level of sectoral and regional asymmetry and inequality of development of individual territories allows to identify the priority and priority directions of development of transport infrastructure.

Key words: transport infrastructure, innovation, spatial inequality, industry-regional asymmetry.

Дата надходження до редакції: 21.08.2019 p. 